\title{
SPEEL DIE BYBEL NOG 'N ROL IN DIE PRAKTIESE TEOLOGIE?
}

\author{
J. Janse van Rensburg ${ }^{1}$
}

\section{ABSTRACT \\ DOES THE BIBLE STILL HAVE A ROLE IN PRACTICAL THEOLOGY?}

It may seem strange that the question is asked: Does the Bible play a significant role in the scientific activities of Practical Theology? Is it possible that a theological discipline, dealing with the practical work of the Church, could ignore the importance of a Biblically based theological theory? There are indeed many variables that could influence Practical Theology in this regard. It could therefore be both necessary and rewarding to investigate this question in more detail.

\section{INLEIDING}

Dat dié vraag hoegenaamd gevra word, behoort vreemd aan te doen. Kan dit wees dat 'n belangrike teologiese vakgebied wat oor die dienswerk van die kerk in al sy fasette handel, nie aan die Bybel 'n betekenisvolle plek toeken nie? Daar is 'n hele aantal veranderlikes wat die beantwoording van hierdie vraag beïnvloed. Daarom is dit die moeite werd om die vraag nader te ondersoek ten einde 'n deeglike antwoord te kan verskaf.

\section{NAVORSINGSPROBLEEM}

'n Dekade of wat gelede sou só 'n vraag waarskynlik nie eens in die gedagtes opgekom het nie. Vroeër was die vakgebied as die "amptelike vakke" bekend en die teologiese vertrekpunt van die vak was dat al die dissiplines in hierdie vakgebied met die ampsbediening te doen het. In hierdie benadering was die Skrif die natuurlike en vanselfsprekende bron vir besinning. Hoe daar gepreek moet word, huisbe-

1 Prof. J. Janse van Renbsurg, Departementshoof, Departement Praktiese Teologie, Fakulteit Teologie, Universiteit van die Vrystaat. Bloemfontein. 9300. E-pos: jjvanr@yebo.co.za 
soek gedoen moet word, pastorale versorging gedoen moet word, kategese aangebied moet word, en so meer, is uit die normering van die Skrif afgelei. Intussen het daar soveel gebeur wat dit nie meer so maklik gemaak het om hierdie metodologie te gebruik nie. Nuwe wetenskaplike metodes soos die historiese en literêr-grammatikale kritiek, die ontwikkeling van menswetenskappe soos sosiologie en sielkunde en die proses van sekularisasie het dit al hoe moeiliker gemaak om die gemeentelike bediening in al sy fasette bloot uit die ampte af te lei. 'n Diakoniologiese epistemologie, wat uit die ampsbenadering voortgevloei het, het al hoe minder die onderskeie dissiplines van die vakgebied tot die ampte en ampsbeskouing beperk. Benewens die Skrif is ook met vrymoedigheid van die insigte van die menswetenskappe gebruik gemaak. Daarna het die paradigmaskuif van modernisme na postmodernisme 'n verdere impak op die paradigmatiese en epistemologiese vertrekpunte van die vakgebied gehad. Al hierdie faktore het daartoe gelei dat die vraag met reg gevra kan word of die Bybel nog toegelaat word om 'n betekenisvolle rol in die vakgebied te speel.

\section{HIPOTESES}

Voorafgaande en 'n indringende studie van die onderskeie dissiplines van die vakgebied lei tot die volgende hipoteses:

3.1 Die stand van Skrifgebruik in die Praktiese Teologie het 'n direkte verband met gekose epistemologiese uitgangspunte.

3.2 Skrifgebruik in die Praktiese Teologie dobber dikwels tussen biblisisme en relativisme.

3.3 Die Skrifbeskouing, Skrifgebruik- en beroep is bepalend vir die aan- of afwesigheid van die Skrif in die basis- en praktykteoretiese teologisering van die vakgebied.

3.4 In die algemeen is die Skrif wel nog in die beoefening van die vakgebied waar te neem, hoewel dit nie altyd op 'n konvensioneeldirekte wyse geskied nie. 


\section{METODOLOGIE}

Ter aanvang moet dit duidelik gestel word dat die navorsingsprobleem geweldig omvangryk is. Ten einde dit deeglik na te vors en 'n verteenwoordigende antwoord aan te bied, sou die navorsing na regte al die dissiplines in die praktiese teologie moes verreken. Daarbenewens sou die navorsing ook al die literatuur wat verteenwoordigend van die betekenisvolle rolspelers in die vakgebied is, moes ontleed ten einde vas te stel in watter mate die Skrif ' $n$ rol in die proses van teologisering speel, indien dit enigsins relevant is. Só 'n omvattende studie val egter eerder binne die spektrum van 'n doktorale studie. Daarom kan hierdie bydrae tot die besinning slegs ' $n$ tendensieuse analise wees wat oor 'n breë terrein relevante literatuur evalueer en 'n paar praktiese teoloë se epistemologiese vertrekpunte ontleed.

\section{DIE EPISTEMOLOGIESE DISKOERS}

Vir die doel van hierdie navorsing kan daar met 'n oorsigtelike samevatting van die diskoers in hierdie verband volstaan word.

Die diakoniologiese benadering word dikwels en meesal vanuit 'n prakties-teologiese epistemologie daarvan beskuldig dat dit op ' $n$ oorvereenvoudigde en biblisistiese wyse die Skrif as 'n handboek wil gebruik en die menswetenskaplike bydraes in die proses ignoreer. Dit is egter al so dikwels aangetoon dat die diakoniologiese benadering sedert 1955 reeds die kennis van menswetenskappe soos die sielkunde erken het. Hoewel B. Wurth (1955:19-32; 111-114) teen die sogenaamde "Pastoral Counseling Movement" gewaarsku het omdat dit die gevaar loop om die pastoraat in die sielkunde te laat opgaan, het hy tog die waarde van die sielkunde erken. Adams (1973:26-40) se algehele verwerping van die sielkunde het egter groot skade aangerig omdat hy sy noutetiese model uitsluitlik op die Bybel wou baseer en die sielkunde as wetenskap verwerp het. Hierna is die diakoniologiese benadering in die algemeen met só ' $n$ biblisistiese benadering vereenselwig. Daar is egter oorvloedige getuienis dat 'n diakoniologiese benadering interdissiplinêr wil teologiseer en dat die Skrif slegs die vertrekpunt is waaruit basisteoretiese beginsels vir die vak afgelei word. Daarbenewens moet die menswetenskaplike kennis ook in die basisteorie verreken word (Trimp [s.a.]:161-163; Heyns en 
Jonker 1977:60-77; De Klerk 1978; 1981; Janse van Rensburg 2000: 78). Die veronderstelling van Dill (1996:146) en Steenkamp (1996:32), as sou die openheid vir menswetenskaplike bydraes aan die invloed van die postmodernisme toegeskryf moet word, is dus gewoon nie met die feite versoenbaar nie.

Hoewel Zerfass (1974) een van die grondleggers van 'n praktiesteologiese kommunikatiewe teorie was, is sy model volledig met ' $n$ diakoniologiese benadering versoenbaar. Die praktyk lewer 'n bepaalde vraagstuk of probleem waarmee Zerfass dan na die teologiese tradisie (daaronder verstaan ek die Skrif, belydenisskrifte en kerklike standpunte en besluite) wil gaan om vas te stel of die kerk op hierdie vraagstuk 'n oplossing kan bied. Vanuit die interaksie tussen teologiese teorie en praxisproblematiek word dan 'n teorie vir die oplossing van die probleem ontwikkel. Die effektiwiteit van hierdie oplossing word in die praktyk getoets en die proses word herhaal totdat 'n effektiewe hantering van die probleem gefasiliteer word.

Terwyl 'n diakoniologiese benadering dus deeglik met die praktyk en konteks rekening wil hou en vanweë die beginsel van interdissiplinariteit selfs met empiriese en fenomenologiese navorsingsmetodes wil werk (oor die voor- en nadele van inter- of intradissiplinariteit word nie hier gehandel nie; sien daarvoor Janse van Rensburg 2000:7980), vorm die Skrif die vertrekpunt vir alle besinning.

H. Jonker (1983:85-87) betoog dat die vertrekpunt vir die praktiese teologie nie die praxis kan wees nie, maar alleen die Waarheid van God. Hy kom tot die gevolgtrekking dat die praktiese teologie hom in die besonder besig hou met die verwerkliking van die Woord van God as Waarheid vir die mens se syn, denke en handelinge en in die menslike verhoudings. Die waarheidsbegrip is by Jonker die hermeneutiese sleutel vir die beoefening van die praktiese teologie. Waarheid is inhoudelik die grond van die verbond, die pneumatologie en die eskatologie (Jonker 1983:97-117). In Jonker se benadering gaan dit dus oor die mens se kommunikatiewe handelinge vanuit die Woord (dus deduktief). Die mens word in sy konteks deur die Waarheid van God gekonfronteer. Onder invloed van Habermas en andere is hierdie benadering in die praktiese teologie omvorm tot die kommunikatiewe handelinge vanuit die praxeologie (dus induktief). 
Wat eersgenoemde betref, is daar oorvloedige getuienis van sulke Skrifgefundeerde modelle. Hendriks (1992:37-88) se basisteorie vir gemeentebou is op eg-diakoniologiese wyse in die Skrifbeginsels gefundeer. Bybelse grondmotiewe soos die Christologie, pneumatologie, verbond en uitverkiesing, sowel as die doksologie is die uitgangspunt vir gemeentebou.

In die pastoraat is Louw (1997) se konvergensiemodel en Van Pelt (1999) se trinitariese benadering tipiese voorbeelde. Louw se konvergensiemodel (1997) is eg diakoniologies en wel om twee redes. Enersyds erken en bepleit hy die direkte en direktiewe gebruik van die Skrif in die pastoraat. Maar andersyds is die Skriftuurlike grondmotiewe van eskatologie, verbond, koninkryk, Christologie en pneumatologie die boustene vir die ontmoetingsgebeure wat tussen God en mens via die pastoraat gefasiliteer word. Wat Louw se model 'n uitmuntende voorbeeld van 'n eg diakoniologiese benadering laat wees, is dat hy daarin geslaag het om die Skrifgefundeerde ontmoetingsgebeure met ' $n$ hermeneutiese benadering te versoen. Deduktief en induktief, direktief en non-direktief is nie konkurrente nie, maar vennote. Dit alles geskied sonder om 'n post-moderne epistemologie te omarm of in biblisisme of fundamentalisme te verval.

Waar die Skrif toegelaat word om so 'n kardinale rol te speel, is dit belangrik om vanuit ' $n$ verantwoordelike eksegese (Müller 1981:2024) te soek na Skrifbeginsels waarmee die praktiese problematiek van prediking, pastoraat ensomeer benader kan word. 'n Biblisistiese benadering, soos wat kenmerkend by Adams se noutetiese model is, moet afgewys word bloot omdat die Bybel nie 'n handboek vir die teologie is nie (Heyns en Jonker 1977:32).

Die vraag is nou wat die situasie binne 'n prakties-teologiese epistemologie sal wees. Voorstanders van 'n kommunikatiewe handelingsteorie vir die praktiese teologie wou nooit doelbewus van die Skrif as vertrekpunt afstand doen nie. Zerfass se model, waarna vroeër verwys is, bevestig dit, terwyl ander wat 'n betekenisvolle bydrae tot die vestiging van die prakties-teologiese epistemologie gelewer het, dikwels na die Skrif verwys of met bepaalde grondmotiewe uit die Skrif (soos koninkryk, verbond, ens.) opereer. 
Hoewel Otto (1970:23-24) byvoorbeeld die praktiese teologie as kritiese teorie in terme van Christelike sowel as nie-christelike fenomene wil beskryf, fundeer Hahn (1970:25-56) in die saamgestelde werk waarvan Otto die redakteur is, 'n besinning oor die nagmaal op 'n diakoniologiese wyse in die Nuwe Testament! Leudesdorff (1970:102105) gaan op dieselfde wyse te werk as daar 'n fundering vir die Diakoniek gegee moet word.

Firet (1977:126-154) se hermeneutiese benadering interpreteer die mens se situasie en probleme in die lig van die Woord. Praktiese teologie is vir hom die teologiese teorie wat die koms van God tot die mens in sy wêreld intermediêrend dien. Skrifbeginsels soos didaché, kerugma en paraklese is kernbeginsels in sy model. Die mens se situasie word in die lig van die Skrif verander terwyl die mens medeverantwoordelikheid vir hierdie vernuwingsproses moet aanvaar. Dit is betekenisvol dat Firet in die 1986-heruitgawe van sy werk wat in 1982 verskyn het, sy teologiese uitgangspunte gehandhaaf het. In die voorwoord stel hy dit uitdruklik dat hy die oorspronklike werk onveranderd laat publiseer omdat hy steeds op dieselfde teologiese uitgangspunte steun (1986:xi). In sy definisie van teologie as wetenskap stel hy (op diakoniologiese wyse) die kennis van God as die oorkoepelende doelwit van die teologie, hoewel hy dit (in kommunikatiewe handelingsteoretiese trant) ook uitbrei na alle funksies in die geloofsgemeenskap wat die kennis van God kan fasiliteer (sien Heitink se bespreking van Firet se definisie in Heitink 1977:19). Só wil Firet dan sowel die teologiese as die wetenskaplike karakter van praktiese teologie handhaaf (1986:5).

Heitink is tans waarskynlik die invloedrykste praktiese teoloog wat ook die kommunikatiewe teorie ondersteun. Tog ontvang die Skrif 'n belangrike plek in sy basisteorie. Heitink (1983:21) erken dat die openbaring teoreties aan die menslike ervaring voorafgaan. Daarom is die "Praxis Gottes" die uitgangspunt. Die teologiese praxis kan nie sonder die verrekening van die Heilige Gees bepaal word nie (1977: 20-21). Heitink formuleer dit só:

Zo komen vanuit de mens en zijn situatie, de handelende Heer en de aktuele ervaring, de verschillende lijnen bij elkaar onder het gezichtspunt van de Praxis Gottes. Er is geen spanning tussen het handelen van God en dat van de mens (Heitink 1977:21). 
God en mens is dus verbondsgenote in die realisering van die evangelie, hoewel die inisiatief wat 'n realisering moontlik maak, altyd van God afkomstig is. Hoewel die diastatiese afstand tussen God en mens, soos by Thurneysen en onder invloed van Barth, nie in absolute sin deur Heitink onderskryf word nie, is die afstand tussen God en mens tog so groot dat dit 'n buitengewone "kreatiewe sprong" van die mens verg om as "verbondspartner" met God te verkeer (1977:144146). In hierdie formulering, wat in die konteks van Heitink se bipolariteit verstaan moet word, is die mens kennelik nie op gelyke vlak met God nie. 'n Mens wonder dus oor Louw se gevolgtrekking dat Heitink se antropologie komplimentaristiese tendense bevat (Louw 1997:88). Rossouw (1983:26) konkludeer dat hier sprake van bi-polariteit is maar nie van versmelting of grensoorskreiding nie.

Heitink stel naamlik 'n alternatiewe moontlike benadering voor. As die mens se perspektief op God as uitgangspunt geneem word, gaan die menslike ervaring aan die openbaring vooraf. Teorie en praxis staan dan in 'n bi-polêre spanning tot mekaar, terwyl die teorie nie oor die praxis voorrang het nie, en die praxis ook nie oor die teorie mag heers nie. Teorie word deur praxis gekorrigeer, en omgekeerd (Heitink 1993:148-150).

Die Skrif speel in hierdie prakties-teologiese benadering 'n betekenisvolle rol. Die mens se kommunikatiewe handelinge moet in diens van die evangelie staan terwyl die praxis deur die beginsels van die Skrif gekorrigeer word (Heitink 1993:153). In die pastoraat beteken dit dat die evangelie gekommunikeer moet word, nie as 'n kerugmatiese verkondiging soos by Thurneysen nie, maar deur 'n interkommunikatiewe dinamika waarin heil gefasiliteer word en die mens deur die daad op die verkondiging moet reageer. Só kom Firet se drie modi van kerugma, didache en paraklese in Heitink se benadering tot die pastoraat tereg en word die koninkryk deur die evangelie in aksie gerealiseer (1977:144-174). Die gestaltegewing van hierdie basisteoretiese uitgangspunte in die pastoraat is ryk aan Skrifverwysings, waaruit Heitink se verbondenheid aan die Skrif op 'n verbredende wyse in teorie en praxis gereflekteer word.

Heitink se bi-polêre benadering tot Skrif en kommunikatiewe handelinge, teorie en praxis, plaas die praktiese teologie in Suid-Afrika 
in konteks. Suid-Afrikaanse praktiese teoloë soos Vos en Pieterse ken ook 'n belangrike plek aan die Skrif toe, al word die basisteorie nie altyd deduktief uit die Skrif afgelei nie, maar induktief uit die mens se kommunikatiewe handelinge. Cas Vos is in hierdie opsig 'n interessante voorbeeld. In sy standaardwerk oor die homiletiek sluit hy by Heitink en Van der Ven aan en kies vir 'n hermeneuties-kommunikatiewe model (1996:11-12). Hy fundeer egter die homiletiek in die Bybel as norm en verbind die homiletiese teorie aan Bybelse grondmotiewe soos koninkryk en verbond (1996:62-128) terwyl ook die rol van die belydenisskrifte verreken word (1996:129-135). Die basisteoretiese gedeelte oor die homiletiek is dan ook ryk aan Skrifverwysings. In hierdie benadering is daar na my mening weinig verskil met 'n diakoniologiese benadering soos ek dit verstaan (Janse van Rensburg 2000: 76-80).

In die prakties-teologiese epistemologie het daar egter ook teoreties 'n paradigmaskuif plaasgevind. Omdat van die vertrekpunt uitgegaan word dat God nie die objek van wetenskaplike navorsing kan wees nie, word die diakoniologiese definisie van teologie (Heyns en Jonker 1977:127-137) vir 'n kommunikatiewe handelingsteorie verruil. Teologie, met name praktiese teologie, is dan die kommunikatiewe handelingsteorieë oor God (Heyns en Pieterse 1990 en Pieterse 1993; 1994).

In hierdie benadering is daar dus tog ruimte vir die Skrif, hoewel die Skrifberoep nie soos by 'n diakoniologiese epistemologie funksioneer nie. Die onafwendbare gevolg was dat die Skrif in sommige gevalle al hoe meer na die periferie van die wetenskapsbeoefening uitgerangeer is. Heitink (1993:120-121) meen dat selfs Firet nie deur die paradigmaskuif onaangeraak gelaat is nie.

Só het die handelingswetenskap 'n al hoe groter rol begin speel. Binne die handelingswetenskaplike teorie is daar met name voorbeelde van 'n prakties-teologiese basisteorie waarin die Skrif op 'n indirekte wyse veronderstel word, maar nie direk by die basisteoretiese formulering betrek word nie. Daiber (1977:9-23) behandel byvoorbeeld die praktiese teologie as onderafdeling van die handelingswetenskaplike teorie. Die praxis is in hierdie benadering só bepalend dat die definisie vir praktiese teologie nie slegs tot die praxis van kerklike 
handelinge beperk word nie. Daiber betoog dat "kerk" in só 'n formulering te abstrak in sistematies-teologiese sin van die woord figureer. Nee, dit moet eerder oor die gemeentelike praxis handel. Dit gaan oor die "empiriese" (konkrete) gemeente. Oor hierdie gemeentelike praxis as Woord- en sakramentsbediening en ander handelinge van 'n gemeentelike lewe verheug Daiber hom.

Tóg kry 'n mens die aanvoeling dat die Skrif in hierdie benadering in die gemeentelike praxis opgaan, 'n uitgangspunt wat veral deur Josuttis bepleit is. In 1974 is daar nog teksverwysings in Josuttis se basisteorie. Tog maak hy reeds tóé 'n saak daarvoor uit dat die evangelie as God se bevrydende heerskappy oor die wêreld deur die "Informationskanälen" van die kerk en die gemeenskap gestalte moet kry. In 1980 gee hy aan hierdie beginsel 'n meer direkte basis as hy daarop wys dat daar in die pastoraat liewer 'n indirekte Skrifgebruik moet wees. Die Skrifgebruik word deur 'n gepraktiseerde evangelie vervang. Dit verteenwoordig 'n indirekte benadering tot die Skrif.

In hierdie benadering word daar dus van 'n diakoniologiese benadering na 'n handelingsteoretiese benadering wegbeweeg. Hierdie beweging het waarskynlik die weg voorberei vir die handelingsteoretiese benadering van die praktiese teologie. Die praktiese teologie is hierin nie "ondogmaties" nie, maar word tog ook nie soos in die verlede deur dogmatiese teorieë oorheers nie (Daiber 1977:206-219).

Die Skrif is in só 'n benadering kennelik subliminaal, indien nie afwesig nie. Bohren (1975:124) se waarskuwing dat die epistemologie van kommunikatiewe handelinge die praxis van God en die Skrif kan relativeer, was dus nie om dowe neute nie. Louw (1993a; 1993b; 1997 ; 1998) het die waarskuwing teen 'n fenomenologiese verabsolutering ten koste van die Skrif en die teologiese aard van die vak dikwels herhaal. Trimp (1981) waarsku ook dat die oorheersing van die Sielkunde daartoe lei dat skuldbelydenis, tug en vergifnis uit die pastoraat verdwyn en dat die mens se primêre behoefte om met sy sonde te handel, só geïgnoreer word. Die karakter van pastoraat het inderdaad al hoe meer 'n sielkundige aanslag gekry, soos met Hiltner se eduktiewe model, of sy teologies-pastorale karakter verloor, soos by Dill \& Kotze (1997) en Kotzé en Kotzé (1997) se narratiewe terapie, wat onafwendbaar op humanisme afstuur (Van Heerden \& Kotzé 
1997:91-92). Ook die prediking het in die slag gebly. Prediking word nie langer as die "So sê die Here, Here" beskou nie, maar word gereduseer tot geselsies waarin die mense eerder met vrae as antwoorde huis toe gestuur word (Janse van Rensburg 2001).

Dit moet egter onmiddellik beklemtoon word dat dit nie altyd en van alle praktiese teoloë gesê kan word nie. Die saak is reeds elders beredeneer dat sommige praktiese teoloë se metodologie van wetenskapsbeoefening eerder met 'n diakoniologiese benadering ooreenstem (Janse van Rensburg 2000:88-89). Dit het tot die gevolgtrekking gelei dat daar eintlike drie kategorieë in die prakties-teologiese paradigma geïdentifiseer kan word. Die eerste kategorie, waarna reeds verwys is, wil met die kommunikatiewe handelingsteorie werk, maar begin dan hulle navorsing met 'n diakoniologiese definisie van teologie en baseer hulle teorievorming op Skrifbeginsels as uitgangspunt.

Die tweede groep werk op 'n indirekte wyse met die Skrifberoep en beginsels. Die kommunikatiewe handelinge van mense is die uitgangspunt, maar dit opereer dan binne die konteks van Skrifbeginsels. 'n Laaste groep het, wat hulle wetenskapsbeoefening betref, klaarblyklik heeltemal van die Skrif afstand gedoen. Die woord "Bybel" word met 'n klein letter geskryf (sien die debat tussen Pieterse en Van Wyk en laasgenoemde se antwoord op eersgenoemde in Van Wyk 1993), enige verwysing na of basering op die belydenisskrifte word as onwetenskaplik bestempel en geen verwysings kom hoegenaamd na die Bybel voor nie. Hierdie groep het volledig by 'n postmoderne paradigma aansluiting gevind.

Ongelukkig het die probleem nie eenvoudiger geword met 'n keuse vir 'n post-moderne epistemologie nie. Vanweë die aard van die postmodernisme sou 'n mens kon verwag dat die Skrif geen rol meer sou speel nie. Immers, van alle "grand narratives" en die beginsel van logosentrisme is in die postmodernisme finaal afskeid geneem (Janse van Rensburg 2000:5-12). Aangesien die outeur dood is en die lewe 'n teks is wat in elke konteks nuut hermeneuties geïnterpreteer moet word, sou dit geen sin hê om die Skrif aan te haal nie, behalwe as elkeen dit mag interpreteer soos hy/sy dit wil verstaan. 
Daar is egter talle voorbeelde van navorsers wat binne die konstruktivisme of soiale konstruksionisme (twee van die bekendste post-moderne epistemologieë) pastorale terapie wil bedryf maar wél ook van die Skrif gebruik wil maak. Dill (1996), Steenkamp (1996) en Joubert (2000) is voorbeelde hiervan. Hulle proefskrifte word in die postmodernisme gefundeer. Tog wil hulle steeds aan die Skrif 'n belangrike plek toeken. Die teenstrydigheid tussen 'n post-moderne verwerping van absolute waarhede enersyds en absolute waardes en die aanvaarding van die Bybel as onfeilbare Woord van God andersyds word in hierdie benadering nie as ' $\mathrm{n}$ contradictio in termini beskou nie. Akademies beoordeel bly die vraag egter of dit moontlik is om tussen twee teenstrydige epistemologieë konsekwente wetenskapsbeoefening te handhaaf. Immers, wie die Skrif aanhaal, is nie meer konsekwent post-modern nie en wie konsekwent post-modern wil wees, kan nie met gesag na enige bron as absolute norm verwys nie.

Hierdie dilemma word byvoorbeeld in Joubert (2000) se proefskrif geïlustreer. Vanuit 'n sosiaal-konstruksionistiese epistemologie kies Joubert vir 'n benadering waarin logosentrisme en grand narratives verruil word vir 'n veelheid van interpretasies (2000:19). Feite word met perspektiewe vervang (2000:28). Twee Skrifverwysings speel in Joubert se keuse 'n belangrike rol. Paulus se relativering van absolute kennis in 1 Korintiërs 13 (2000:19) en sy keuse om vir almal alles te wees in 1 Korintiërs 9:19-22 (2000:22-23) is vir Joubert die Bybelse motivering om nie met absolute waarhede en waardes te werk nie. Hy wil met hierdie benadering die saak van die ontmagtigde gemargenaliseerdes opneem en die vrees by hulle wegneem dat hulle beskouings en interpretasies van die Skrif verwerp sal word en hulle vir hulle homoseksualiteit, egbreuk of konkubinaat veroordeel sal word (2000: 28-30).

Hoewel die motivering en bedoeling van so 'n gekose epistemologie lofwaardig is, illustreer dit juis die probleem van Skrifgebruik binne 'n post-moderne epistemologie. Ons sou daarop kon wys dat die wyse waarop 1 Korintiërs 9 en 13 hier buite eksegetiese konteks aangewend word, reeds die probleem van 'n verkeerde Skrifberoep illustreer. 'n Belangriker vraag is egter hoe dit moontlik is om die twee gekose uiterstes konsekwent te handhaaf. Joubert stel dit naamlik onomwonde dat die Skrif as norm vir hom die uitgangspunt is 
(2000:32). Tóg wil hy nie in etiese gevalle soos homoseksualiteit en egbreuk met waarhede werk nie en ook nie veroordelend wees nie. Die vraag is hoe die pastor dan op die lang duur aan die Skrifnormering getrou kan bly. Dit word ook 'n vraag hoe die Christelike etiek dan in die pastorale terapie tereg kom (Janse van Rensburg 1999: 158-167; 2000:64-75).

In die pastorale terapie word hierdie dilemma akuut geillustreer in die non-direktiewe "client is the expert"-benadering (Anderson en Goolishian 1992) en die unieke uitkomste van die narratiewe terapie. Omdat die kliënt die ekspert is en self sy eie unieke uitkoms moet konstrueer, lê dit nie op die weg van die terapeut om deduktief en direktief te werk nie. Waar met die konstruktiwisme gewerk word, is dit ook hoegenaamd nie die doel om mense deur middel van die terapie te verander nie (Tomm \& Lannamann 1988:37; Maturana 1985:43). In só 'n benadering is die terapeut daartoe verbind om die kliënt in die keuse van 'n unieke uitkoms te steun, ook al sou daardie unieke uitkoms nie met die Skrif ooreenstem nie.

Pastorale terapeute wat met 'n post-moderne epistemologie wil werk, ontken dat hulle gekose paradigma hulle daartoe verbind om die kliënt in sy gekose unieke uitkoms te ondersteun. Hulle behou die reg voor om dan met Bybelse korrektiewe te kom. Dán is die terapeut egter nie meer non-direktief nie en ook nie meer post-modern nie omdat ewige waarhede en vasstaande norme skielik nou weer geldend is. Die praktyk het dan ook bewys dat die meeste pastorale terapeute nie konsekwent post-modern kan of wil wees nie en ook nie in staat is om die Skrifnormering konsekwent buite rekening te laat nie.

Gelowige post-moderne navorsers voel skynbaar "moreel” verplig om die Skrif te verreken. Dit word egter op so 'n wyse gedoen dat die Skrif geweld aangedoen word. Een voorbeeld hiervan is Dill en Kotzé (1997:23) se uiteensetting van 'n nuwe epistemologie vir die praktiese teologie, waarin morele gesag nie buite die mens gesetel is nie (dus ook nie in God of die Skrif nie), maar in die verhoudings waarin die mens staan. Die vraag of dit met die Skrif ooreenstem, word deur Dill en Kotzé beantwoord deur die Skrifboodskap in verhoudings te laat opgaan. 'n Epistemologie wat dus die primaat aan verhoudings toeken, moet dus noodwendig "Bybels" wees. Só 'n 
Skrifberoep is hoogs bedenklik. In hierdie benadering word kliënte al hoe meer met 'n soort terapie bedien wat nie die naam "pastorale terapie" werd is nie. Nóg die waarhede of beginsels van die Skrif, nóg gebed, nóg enige handeling of strategie met 'n pastorale karakter is deel van die terapie. Só 'n terapie is dus per definisie nie pastorale terapie nie en ook nie psigoterapie nie, omdat diagnose prinsipieel ook normatief is en met absolute waardesisteme en evaluering te werk gaan. Pastorale terapie word dan sosiaal-konstruksionistiese narratiewe terapie (Dill \& Kotzé 1997; Kotzé \& Kotzé 1997).

\section{SAMEVATTENDE EVALUERING}

Die besinning oor die plek van die Skrif in die praktiese teologie is van wesenlike belang. In die ontwikkelingsproses van die vakgebied het daar wedersydse wantroue tussen voorstanders van 'n diakoniologiese en 'n prakties-teologiese epistemologie ontwikkel. Eersgenoemde is van biblisisme en ' $n$ miskenning van die praxis beskuldig, terwyl laasgenoemde daarvan verdink is dat die Skrif nie meer toegelaat word om 'n rol te speel nie. Dit beteken dat dit nie net om die vraag gaan of die Bybel toegelaat word om 'n rol in die praktiese teologie te speel nie, maar dat daar tog ook 'n korrekte gebruik van die Skrif moet wees.

Fundamentalisme as die een teenpool word aangespreek deur die behoefte aan afstand, om nie alles lynreg en op 'n biblisisties-oorvereenvoudigde wyse uit die Skrif te wil aflei nie. Relativisme kan daarenteen in vele vorms voorkom en moet weer deur 'n korrekte Skrifgebruik getemper word. Relativisme kan in growwe of gesofistikeerde vorm in 'n post-moderne paradigma voorkom. Dan word die hermeneutiese verstaan van die teks as metafoor van die lewe deur elke individu binne sy eie konteks bepaal. In navolging van Derrida se la differánce sou die interpretasie van die teks van die lewe en die teks van die Bybel nog verder en meer radikaal hermeneuties geïnterpreteer kon word.

Maar daar is ook 'n meer matige relativering van die Skrif waarmee rekening gehou moet word. Dit gebeur wanneer die Bybel op geen direkte wyse geraadpleeg of ter sprake gebring word nie. Op 'n indirekte wyse word die Skrifwaarhede veronderstel. Metafories beskryf 
is die Bybel slegs die dékor waarteen die drama van die wetenskapsbeoefening afspeel.

Die vraag is nou waar presies 'n ekwilibrium gesoek moet word. Heitink se beginsel van bi-polariteit kan ons hiermee help. Dit impliseer dat dit nie nodig is om die een epistemologie teenoor die ander af te speel nie. Beide benaderings kan in 'n spanningsvolle verhouding tot mekaar staan. Daarmee word bedoel dat die aard van die bepaalde navorsing behoort te bepaal of 'n direkte en deduktiewe Skrifhantering die wenslikste sou wees, terwyl ander tipes navorsing weer 'n meer indirekte Skrifgebruik en 'n induktiewe benadering veronderstel. Dit is reeds elders beredeneer (Janse van Rensburg 2001:344-346) dat 'n keuse tussen 'n induktiewe of deduktiewe benadering tot die prediking onnodig is. Dit geld ook van die vakgebied as geheel. 'n Eksklusiewe benadering behoort dus met ' $n$ inklusiewe benadering vervang te word.

Só 'n bi-polêre benadering veronderstel dat 'n eksklusiewe keuse vir 'n diakoniologiese of 'n prakties-teologiese epistemologie onnodig is. Die konkurensie wat daar in die verlede was en wat in die vakliteratuur baie prominent uitstaan, behoort deur 'n bi-polêre benadering opgeklaar te word. 'n Inklusiewe benadering is moontlik wanneer die aard van die navorsing toegelaat word om die keuse van 'n epistemologie te bepaal. Indien daar byvoorbeeld navorsing gedoen word oor die Ou Testament en die liturgie, sou 'n diakoniologiese vertekpunt aangedui wees. Dán wil die navorser eers vasstel watter beginsels uit die Ou Testament geldig is vir vandag voordat dit moontlik is om dit in die konteks en behoeftes van vandag te aktualiseer. Die benadering is dán: Skrif, teologiese teorie en dan meta-teorie. Wil die navorser egter vasstel waarom adolessente na aflegging van belydenis al hoe minder kerklik betrokke is, sou 'n prakties-teologiese benadering weer aangedui wees. In so 'n navorsing kan empirie en fenomenologie selfs 'n oorheersende rol speel, soos by Van der Ven (1994), wat in 1985 reeds 'n kritiese gesprek met die gesekulariseerde samelewing as Leitmotiv aanvaar het (1985:20).

Die gegewens wat in hierdie navorsing onder die loep gekom het, dui onteenseglik daarop dat die Skrif in die praktiese teologie hoofsaaklik toegelaat word om 'n rol te speel. Op 'n direkte en deduktiewe wyse of op ' $n$ induktiewe en subliminale wyse is die Skrif be- 
palend vir die vakgebied, watter epistemologiese keuses ookal gemaak word. Die plek wat aan die Skrif toegeken word en die wyse waarop dit figureer, mag varieer. Dit is egter duidelik dat dit nie 'n algemene tendens is om die Skrif in die vakgebied te ignoreer nie. Daarvoor kan ons alleen maar dankbaar wees. Immers, as die Skrif in die teologiese wetenskapsbeoefening wegval, kan die teologiese karakter moeilik gehandhaaf word.

\section{BIBLIOGRAFIE}

ADAMS J A

1973. Competent to counsel. Grand Rapids: Presbyterian and Reformed Publishing Company.

\section{ANDERSON H \& GOOLISHIAN H}

1992. The client is the expert: a not-knowing approach to therapy. In: S. McNamee \& K.J. Gergen, (eds.), Therapy as social construction. London: Sage.

BOHREN R

1975. Dass Gott schön werde: praktische Theologie als theologische Asthetik. München: Kaizer Verlag.

BRILLENBURG WURTH G

1955. Christelijke zielszorg in het licht der moderne psychologie. Kampen: Kok.

DAIBER KARL-FrITZ

1977. Grundriss der Praktischen Theologie als Handelungswissenschaft. Grünewald: Kaiser Verlag.

De KLeRK J J

1978. Herderkunde. Pretoria: N.G. Kerkboekhandel.

1981. Pastoraat en die ander "pastorale" wetenskappe. Professorale intreerede. Bloemfontein: U.O.V.S.

DILL J

1996. 'n Basisteorie vir pastorale terapie in die lig van post-moderne epistemologie. Ongepubliseerde proefskrif. Bloemfontein: U.O.V.S. 


\section{Dill J \& KotZÉ D J}

1997. Verkenning van 'n post-moderne epistemologiese konteks vir die Praktiese Teologie. Acta Theologica 17(1):1-23.

\section{FIRET J}

1977. Het agogisch moment in het pastoraal optreden. Kampen: J.H. Kok.

1986. Dynamics in pastoring. Grand Rapids: W.B. Eerdmans.

\section{HAHN F}

1970. Abendmahl. In: G. Otto, (Hrsg.), Practisch Theologisches Handbuch. Hamburg: Furche.

\section{Heitink G}

1977. Pastoraat als bulpverlening. Kampen: Kok.

1983. Gids voor het pastoraat. Kampen: J.H. Kok.

1993. Practische theologie: geschiedenis, theorie, handelingsvelden. Kampen: Kok.

\section{HENDRIKS J}

1992. Strategiese beplanning in die gemeente. Wellington: Hugenote Uitgewers.

\section{HeYNS J A \& JONKER W D}

1977. Op weg met die teologie. Pretoria: N.G. Kerkboekhandel.

\section{Heyns L M \& Pieterse H J C}

1990. A primer in practical theology. Pretoria: Gnosis.

\section{JANSE VAN RENSBURG J}

1999. Etiek en pastoraat in hermeneutiese konteks. Tydskrif vir Geesteswetenskappe 39(2):158-167.

2000. The paradigm shift. Pretoria: Van Schaik.

2001. The influence of post-modern epistemology on preaching. NGTT 42 (3\&4):340-347.

\section{JONKER H}

1983. Theologische Praxis. Nijkerk: Callenbach.

\section{JosutTis M}

1974. Praxis des Evangeliums zwischen Politik und Religion. München: Kaiser Verlag. 1980. Praxis des Evangeliums zwischen Politik und Religion. München: Kaiser Verlag.

\section{JOUBERT B F}

2000. The social coinonial construction of pastoral therapy in clergy training. Ongepubliseerde proefskrif. Bloemfontein: U.O.V.S.

\section{KoTZÉ E \& KoTZÉ D J}

1997. Social construction as a postmodern discourse: an epistemology for conversational therapeutic practice. Acta Theologica 17(1):1-23.

\section{LEUDESDORFF R}

1970. Diakonie. In: G. Otto (Hrsg.), Practisch Theologisches Handbuch. Hamburg: Furche. 


\section{LOUW D J}

1993a. Praktiese Teologie — 'n fenomenologiese stuiptrekking? Praktiese Teologie in Suid-Afrika 8(2):2-6-209.

1993b. Kroniek: praktiese teologie/pastoraat/gemeentebediening. Praktiese Teologie in Suid-Afrika 8(2):193-196.

1997. Pastoraat as vertolking en ontmoeting. Kaapstad: Lux Verbi.

1998. Hoe teologies is die praktiese teologie en hoe prakties is die teologie? Ontwerp vir 'n prakties-teologiese hermeneutiek. Praktiese Teologie in Suid-Afrika 13(1):43-63.

\section{MATURANA H}

1985. An interview with Humberto Maturana. Networker May/June:36-43.

\section{MÜller B A}

1981. Skrifgebruik in die pastoraat. Stellenbosse Teologiese Studies nr. 8, Julie. Kaapstad: N.G. Kerkuitgewers.

\section{OTTO G (HRsG.)}

1970. Practisch Theologisches Handbuch. Hamburg: Furche.

\section{Pieterse H J C}

1993. Die probleem van normatiwiteit en rasionaliteit in die beoefening van die praktiese teologie. Praktiese Teologie in Suid-Afrika 8(2):197-203

1994. Metateorie as wetenskapsbenadering in die praktiese teologie. Praktiese Teologie in Suid-Afrika 8(2):93-100.

\section{Rossouw P J}

1983. Grondlyne van 'n pastorale model — Gerben Heitink. Pretoria: N.G. Kerkboekhandel.

\section{STEENKAMP L M}

1996. 'n Kognitiewe benadering tot pastorale terapie vanuit die teologie van Paulus. Ongepubliseerde proefskrif. Bloemfontein: U.O.V.S.

\section{TOMM K \& LANNAMANN J W}

1988. Costructivism applied: the constructivist challenge. Networker September/ October:34vv.

\section{TRIMP C}

[s.a.] Diakoniologie. In: Oriëntatie in de Theologie. Studiegids saamgestel deur die hoogleraars te Kampen (geen spesifieke redakteur). Kampen: De Vuurbraak. 1981. Media Vitae. Groninger: De Vuurbraak.

\section{VAN DER VEN H}

1985. Pastoraal tussen ideaal en wederkerigheid. Kampen: Kok.

1994. Empirical methodology in practical theology: why and how? Praktiese Teologie in Suid-Afrika 9(1):29-44. 
Janse van Rensburg Speel die Bybel nog 'n rol?

Van Heerden P R \& Kotzé D J

1997. Die pastorale gesprek binne 'n narratiewe diakonale pastoraat. Acta Theologica 17(1):81-98.

VAN Pelt J W

1999. Pastoraat in trinitarisch perspectief. Groen: Hoerenveen.

VAN WYK A G

1993. Respons op: "Praktiese teologie as teologiese wetenskap binne die teologiese fakulteit" — prof. H.J.C. Pieterse. Practical Theology in South Africa 8(1): 57-62.

Vos C J A

1996. Die volheid daarvan (I). Pretoria: RGN.

Zerfass R \& GREINDCHE N

1974. Einführung in die Praktische Theologie. Kaiser: Grünewald.

Trefwoorde

Bybel

Epistemologie

Postmodernisme

Diakoniologie

Praktiese teologie
Keywords

Bible

Epistemology

Postmodernism

Diaconiology

Practical Theology 